\title{
Abstract of Thesis Approved for the PhD Degree at the Faculty of Medicine, Health Sciences Center, Kuwait University, Kuwait
}

\section{PhD Degree}

\section{1}

\section{The Role of Different Human Metapneumovirus Genotypes in Acute Respiratory Tract Infection and Disease in Kuwait Using Advanced Molecular Techniques \\ Mariam Badran Al-Turab}

Department of Microbiology, Faculty of Medicine, Health Science Center, Kuwait University, Kuwait

Human metapneumovirus (hMPV) is a respiratory pathogen that was discovered in 2001 in the Netherlands. Since its discovery it was recognized as an important cause of both upper and lower respiratory tract infections (RTIs), in all age groups and in all geographical areas. The role of hMPV in causing RTIs in Kuwait has not been investigated. Therefore, molecular methods for the hMPV detection among patients with RTIs were developed and established for routine detection of this virus. Indeed, several molecular methods were used to accomplish this aim that included RT-PCR, in-house and commercial real-time RT-PCR for both hMPV detection and quantification, and in-house and commercial microarray assays for both hMPV detection and genotyping. In this study, the frequency of hMPV infection in Kuwait in relation to other respiratory viruses and its seasonal distribution were investigated. Furthermore, the prevalence of different hMPV genotypes circulating in this area were determined by direct sequencing, and the potential correlation between different hMPV geno- types and the severity of respiratory tract disease was analyzed. In addition, the association between RNA load of different hMPV genotypes and its effect on the outcome and prognosis of hMPV disease was also investigated. Our results show that the prevalence of hMPV infection in Kuwait among patients with RTIs was almost $5 \%$; both genotypes A and B were detected in Kuwait with no predominance of one over the other. Furthermore, there was no evidence for a direct correlation between hMPV genotypes and the severity of the clinical outcome. Moreover, hMPV infection was seasonal, and peaks occurred during winter and spring. hMPV infection was detected in all age groups, but mostly in young children and the elderly. Most of hMPV-positive patients presented with lower RTIs such as pneumonia and bronchopneumonia. The major cause of lower RTIs in our study population was human rhinovirus (hRV; $30 \%)$, followed by hMPV (22\%), and then human respiratory syncytial virus (13\%). The proportion of hMPV coinfection with other respiratory viruses was almost 19\% among hMPV-positive cases (mainly hRV, 13\%). This coinfection was associated with severer disease and prolonged hospital stay. High viral RNA load in hMPV-positive patients with lower RTIs correlated well with the severity of clinical symptoms and virus replication rate. Our results highlight the importance of hMPV infection as an important cause of severe lower RTI, especially among children and elderly subjects in Kuwait.

Prof. Widad Al Nakib (Supervisor)

Prof. Fahd Al Mulla (Co-supervisor)

Dr. Wassim Chehadeh (Co-supervisor)

Supported by a fellowship from the College of Graduate Studies and Kuwait University Research Administration grant No. YM05/09.

\begin{tabular}{ll}
\hline KARGER 125/\% & $\begin{array}{l}\text { @ 2015 S. Karger AG, Basel } \\
\text { 1011-7571/15/0246-0592\$39.50/0 Openger }\end{array}$ \\
$\begin{array}{l}\text { E-Mail karger@karger.com } \\
\text { www.karger.com/mpp }\end{array}$ & $\begin{array}{l}\text { This is an Open Access article licensed under the terms of the } \\
\text { Creative Commons Attribution-NonCommercial 3.0 Un- } \\
\text { ported license (CC BY-NC) (www.karger.com/OA-license), } \\
\text { applicable to the online version of the article only. Distribu- } \\
\text { tion permitted for non-commercial purposes only. }\end{array}$
\end{tabular}

